\title{
PENGARUH PERSEPSI WAJIB PAJAK ATAS PEMAHAMAN PERATURAN PERPAJAKAN, AKUNTABILTAS PEMERINTAH, KESADARAN WAJIB PAJAK DAN SANKSI PAJAK TERHADAP KEPATUHAN WAJIB PAJAK
}

\author{
Anton Robiansyah ${ }^{1)}$, Pratana Puspa Midiastuty2), Eddy Suranta ${ }^{3)}$, Suparsiyem ${ }^{4}$ \\ 1) Fakultas Ekonomi Universitas Terbuka, Tangerang \\ Email $^{1}$ anton.robiansyah@ecampus.ut.ac.id \\ 2,3,4) Jurusan Akuntansi, Fakultas Ekonomi dan Bisnis Universitas Bengkulu, Bengkulu \\ Emai12)ppmidiastuty@unib.ac.id \\ Email $^{3)}$ eddy.suranta@unib.ac.id
}

\begin{abstract}
This study aims to provide empirical evidence that understanding tax regulations, government accountability, awareness of taxpayers and tax penalties have a positive effect on taxpayer compliance. the data used in this study is primary data. Primary data was obtained from questionnaires distributed to MSMEs' Individual Taxpayers in Bengkulu City. The number of questionnaires distributed was 130 questionnaires, but only 102 questionnaires were processed. Data were analyzed using multiple linear regression analysis using the SPSS program. The results of testing hypotheses show understanding of taxation regulations and government accountability does not affect taxpayer compliance, while taxpayer awareness and tax sanctions have a positive effect on taxpayer compliance. The results of the study show that the lower the taxpayer's understanding of taxation regulations, and the lower the accountability of the government will make taxpayers increasingly disobedient in carrying out their tax obligations. Whereas, the higher the awareness of taxpayers and the more assertive the sanctions applied by the Director - General of taxation, the more obedient Individual Taxpayers who have businesses in Bengkulu City will carry out their tax obligations.
\end{abstract}

Keywords: Taxpayer Compliance, Understanding Tax Regulations, Government Accountability, Taxpayer Awareness, Tax Sanctions.

\section{PENDAHULUAN}

Salah satu usaha untuk mewujudkan kemandirian suatu bangsa atau negara dalam pembiayaan pembangunan adalah menggali sumber dana yang berasal dari dalam negeri berupa pajak. Pajak digunakan untuk membiayai pembangunan yang berguna bagi kepentingan bersama. Pajak merupakan pendapatan negara yang berasal dari masyarakat dan pajak juga dapat dikatakan sebagai pendapatan negara yang sangat potensial, karena manfaat pajak bagi pembangunan negara mempunyai pengaruh yang sangat besar, oleh sebab itu pajak memiliki peran yang sangat penting dan ditunjukkan terhadap kesejahteraan masyarakat. Penerimaan pajak dari tahun ke tahun akan mengalami perubahan sedemikian rupa tergantung dari tinggi maupun rendahnya kepatuhan wajib pajak, oleh sebab itu perlu adanya kesadaran dari masyarakat untuk taat dalam memenuhi kewajiban perpajakannya (Astina dan Setiawan, 2018). 
Terdapat isu mengenai rasio Kepatuhan Wajib Pajak di Provinsi Bengkulu pada tahun 2017 mengalami peningkatan. Dengan jumlah Wajib Pajak terdaftar sebanyak 236.987 Wajib Pajak, maka harapan untuk mencapai rasio kepatuhan yang optimal dapat diwujudkan. Rasio kepatuhan penyampaian SPT tahunan PPh tahun 2017 untuk Wajib Pajak Orang Pribadi sudah cukup optimal, akan tetapi untuk SPT PPh OP Non Karyawan dan Badan yang ditargetkan sebesar 45 persen dan Wajib Pajak terdaftar Wajib SPT baru dapat direalisasikan 43,24 persen sehingga masih perlu ditingkatkan lagi kepatuhan penyampaian SPT Tahunan Wajib Pajak Orang Pribadi Non Karyawan dan Badan di wilayah Provinsi Bengkulu (www.garudadaily.com).

Wajib pajak orang pribadi non karyawan khususnya wajib pajak yang memiliki Usaha Mikro Kecil dan Menengah (UMKM) yang tidak mematuhi peraturan perpajakannya kemungkinan dikarenakan wajib pajak tersebut menganggap terlalu tinggi atau tidak adil penerapan pajak penghasilan yang diterapkan oleh pemerintah. Penerapan peraturan pemerintah nomor 46 tahun 2013 memberlakukan pajak 1\% untuk pengusaha UMKM dengan omset (peredaran bruto) mulai 1 hingga maksimal hingga Rp 4,8 miliar per tahun. Dan pajak dipungut 1\% (satu persen) tiap bulan berdasarkan omset penjualan di bulan itu. Namun penerapan PPH final 1 persen dianggap terlalu besar, sehingga dalam perjalanannya banyak yang protes atau tidak setuju terhadap peraturan tersebut (www.liputan6.com). Maka dari itu pemerintah mengeluarkan peraturan terbaru mengenai penurunan Pph final yang tercantum di peraturan pemerintah nomor 23 tahun 2018 yang memberlakukan pajak $0,5 \%$ untuk pengusaha UMKM dengan omset (peredaran bruto) mulai 1 hingga maksimal Rp. 4,8 miliar per tahun. Peraturan tersebut mulai diberlakukan pada tanggal 1 juli 2018.

Adanya penurunan pengenaan tarif pajak dari 1 persen menjadi 0,5 persen diharapkan dapat mendorong peran serta masyarakat dalam kegiatan ekonomi formal. Sehingga ke depan akan memberikan keadilan dan kemudahan dalam melaksanakan kewajiban pajak bagi UMKM. Dengan begitu, diharapkan akan mampu mendorong penerimaan pajak lebih besar (www.liputan6.com). Meskipun telah diberlakukan penurun tarif pajak, namun tidak menutup kemungkinan untuk wajib pajak melanggar peraturan perpajakan, maka dari itu pemerintah harus memberikan berbagai keringanan dan kemudahan bagi UMKM, termasuk keringanan dan kemudahan UMKM untuk memenuhi kewajiban perpajakannya. Keringanan beban pajak perlu diberikan mengingat kemampuan Keuangan UMKM yang relatif masih sangat rendah dan keterbatasan jumlah maupun kualitas sumber daya manusia yang ada di UMKM, maka UMKM perlu diberikan kemudahan untuk melaksanakan kewajiban perpajakannya. Harus dibuat sistem perpajakan yang sangat sederhana bagi UMKM Untuk memenuhi kewajiban perpajakannya (Lim dan Indrawati, 2013).

Upaya tersebut dilakukan guna memberikan dorongan kepada wajib pajak untuk patuh terhadap aturan perpajakan. Kepatuhan perpajakan itu sendiri adalah seorang wajib pajak yang mempunyai kemampuan dan keinginan untuk patuh atau mengikuti hukumhukum pajak yang berlaku yang ditentukan oleh etika, lingkungan hukum, dan faktor-faktor situasional lainnya pada waktu dan tempat secara bersamaan (Latifah, 2013), atau dengan kata lain kepatuhan wajib pajak itu pada dasarnya adalah wajib pajak secara suka rela mendaftarkan diri, menyetorkan kembali surat pemberitahuan (SPT), menghitung dan membayar pajak terhutang serta patuh dalam membayar tunggakan perpajakannya. Adanya isu mengenai kepatuhan menjadi hal yang penting karena ketidak patuhan secara bersamaan akan menimbulkan upaya menghindari pajak (Yusril dkk, 2015). Isu mengenai kepatuhan 
wajib pajak itu sendiri telah banyak diteliti oleh peneliti sebelumnya, yaitu berdasarkan hasil temuan dari Razak dan Adafula (2013), Dahruji (2011), Hardiningsih dan Yulianawati (2011), Saputra (2015), Cahyadi dan Jati (2016), Imaniati (2016), Khasanah (2016), Astina dan Setiawan (2018) yang menemukan bahwa kepatuhan wajib pajak dapat dipengaruhi oleh beberapa faktor yaitu pemahaman peraturan perpajakan, akuntabilitas pemerintah, kesadaran wajib pajak dan sanksi pajak.

Beberapa penelitian tersebut menggunakan teori TPB (Theory of Planned Behavior) untuk menjelaskan perilaku wajib pajak dalam mematuhi peraturan perpajakannya. TPB menjelaskan bahwa perilaku seseorang dipengaruhi oleh minat berperilaku, dimana minat berperilaku dipengaruhi variabel sikap, norma subyektif dan kontrol perilaku yang dipersepsikan. Dalam penelitian ini TPB dijadikan dasar untuk menilai apakah kepatuhan WP dapat dipengaruhi oleh adanya pemahaman perpajakan, persepsi atas akuntabilitas, kesadaran wajib pajak dan sanksi pajak. Hal tersebut digunakan untuk mengetahui tingkat kepatuhan wajib pajak orang pribadi di sektor Usaha Mikro Kecil dan Menengah (UMKM) di Kota Bengkulu.

Kesadaran wajib pajak berkaitan dengan variabel sikap yaitu keyakinan akan hasil dari membayar pajak, yakin bahwa hasil yang akan diterima setelah patuh membayar pajak akan memberikan kontribusi nyata bagi pembangunan dan pembiayaan negara. Selain itu akuntabilitas pemerintah berkaitan dengan norma subjektif yaitu keyakinan individu yang dipengaruhi oleh orang lain atau lingkungan mengenai harapan akan hasil dari tindakan yang nantinya akan mendorong individu untuk berperilaku, yakni adanya transparansi dan akuntabilitas dari Direktorat Jendral Pajak akan memberikan keyakinan bahwa pajak yang dibayarkan dikelola dengan baik dan digunakan untuk kepentingan bersama sehingga memberikan motivasi kepada wajib pajak untuk patuh dalam membayar pajak. Sedangkan sanksi pajak berkaitan dengan kontrol perilaku yang dipersepsikan yang menjelaskan mengenai dukungan atau hambatan untuk berperilaku, yakni dengan adanya sanksi yang tegas oleh direktorat jendral pajak akan memberikan hambatan wajib pajak untuk berperilaku, hal tersebut akan memberikan efek jera apabila wajib pajak tidak patuh dalam membayar pajak. Kontrol perilaku juga berkaitan dengan pemahaman wajib pajak terhadap peraturan perpajakan yaitu adanya pemahaman yang luas mengenai tatacara dan UU peraturan perpajakan maka hal tersebut dapat memberikan kemudahan/ dukungan bagi wajib pajak untuk mematuhi peraturan perpajakan.

Ada beberapa kemungkinan yang menyebabkan WP berperilaku tidak patuh dalam melaporkan kewajiban perpajakannya, yaitu mengenai pemahaman peraturan perpajakan. Pemahaman peraturan perpajakan merupakan suatu cara wajib pajak dalam memahami peraturan perpajakan yang telah ditentukan oleh pemerintah. Pemahaman tersebut bertujuan untuk memahami dan mengetahui mengenai peraturan dan undang-undang serta tata cara perpajakan dan menerapkannya untuk melakukan kegiatan perpajakan seperti, membayar pajak, melaporkan SPT, dan sebagainya. Wajib pajak yang tidak memahami peraturan perpajakan secara jelas cenderung akan menjadi wajib pajak yang tidak taat. Jelas bahwa semakin paham wajib pajak terhadap peraturan perpajakan, maka semakin paham pula wajib pajak terhadap sanksi yang akan diterima bila melalaikan kewajiban perpajakan mereka (Hardiningsih dan Yulianawati, 2011).

Dalam hubungannya dengan persepsi atas akuntabilitas pemerintah, untuk mencapai kepatuhan wajib pajak tidak hanya cukup dengan pemahaman peraturan perpajakan saja, pada kenyataannya dibutuhkan kepercayaan wajib pajak akan penyelenggara atau pemerintah. Maraknya kasus penggelapan pajak menimbulkan dampak 
menurunnya keyakinan wajib pajak akan petugas pajak. Masyarakat merasa bahwa penerimaan pajak banyak dipergunakan untuk kepentingan pribadi, bukan untuk pembangunan negara. Hal ini berdampak secara tidak langsung pada kepatuhan wajib pajak. Pemerintah dituntut untuk transparan dan menunjukkan akuntabilitasnya. Transparansi yang diharapkan adalah adanya keterbukaan pemerintah akan alokasi atau penggunaan penerimaan pajak pada pembangunan. Direktorat Jenderal Pajak diharapkan untuk memberikan informasi yang lebih jelas akan alokasi penerimaan pajak yang tepat pada sasaran dan masyarakat dapat merasakan secara langsung maupun tidak langsung timbal balik dari alokasi penerimaan pajak dalam pembangunan. Hal ini akan berdampak pada meningkatnya keyakinan masayarakat sehingga tingkat kepatuhan wajib pajak untuk membayar pajak tinggi (Dartini dan Jati, 2016).

Selain adanya pemahaman dari wajib pajak dan persepsi atas akuntabilitas pemerintah juga diperlukan adanya kesadaran wajib pajak. Kesadaran wajib pajak atas fungsi perpajakan sebagai pembiayaan negara sangat diperlukan untuk meningkatkan kepatuhan wajib pajak. Kesadaran wajib pajak dalam perpajakan maksudnya adalah suatu rasa yang timbul dari dalam diri wajib pajak atas kewajibanya untuk membayar pajak dengan ikhlas tanpa adanya unsur paksaan dari pihak manapun. Selanjutnya kesadaran dilihat dari sejauh mana ketepatan waktu pembayaran wajib pajak, sejauh mana kesadaranya dalam membayar pajak apakah mereka benar-benar sadar dari dalam dirinya sendiri atau sekedar membayar karena takut kena denda (Dahruji, 2011). Maka dari itu adanya kesadaran dari wajib pajak dapat meningkatkan kepatuhan wajib pajak.

Hal lain yang dapat menjadikan wajib pajak patuh terhadap peraturan perpajakan adalah sanksi perpajakan. Menurut Kamus Besar Bahasa Indonesia sanksi merupakan tanggungan untuk memaksa orang menepati perjanjian atau menepati ketentuan undangundang. Sanksi perpajakan merupakan jaminan bahwa ketentuan peraturan perundangundangan perpajakan akan dipatuhi dengan baik, atau bisa dengan kata lain sanksi perpajakan merupakan alat pencegah agar wajib pajak tidak melanggar norma perpajakan. Oleh karena itu sanksi yang tegas dan efektif diharapkan akan membuat wajib pajak patuh dalam hal perpajakan (Latifah, 2013).

Penelitian ini meneliti kembali penelitian dari Razak dan Adafula (2013) dimana Razak dan Adafula (2013) menemukan bukti bahwa pemahaman wajib pajak tidak secara signifikan mempengaruhi sikap wajib pajak dan tidak berkorelasi positif dengan keputusan kepatuhan pajak. Hal ini mengindikasikan bahwa karena sebagian besar pendidikan wajib pajak adalah rendah, maka ini akan menimbulkan kurangnya pengetahuan tentang peraturan pajak, sehingga pemahaman tentang peraturan pajak pun juga sangat kurang. Oleh karena itu wajib pajak juga tidak akan sadar tentang kemauan membayar pajak. dan persepsi atas akuntabilitas tidak secara signifikan mempengaruhi sikap wajib pajak dan tidak berkorelasi positif dengan keputusan kepatuhan pajak, hal tersebut disimpulkan bahwa sebagian orang meragukan manfaat sebenarnya dari membayar pajak. Pendidikan pajak sangat penting karena tingkat transparansi dalam penggunaan pendapatan pemerintah mempengaruhi kepatuhan pajak. Hasil temuan ini berbeda dengan penelitian terdahulu yang dilakukan oleh Dahruji (2011), Khasanah (2016), Astina dan Setiawan (2018) yang mengatakan bahwa pemahaman wajib pajak berpengaruh positif dan signifikan terhadap kepatuhan wajib pajak. Penelitian Imaniati (2016) membuktikan bahwa pemahaman perpajakan berpengaruh positif dan signifikan terhadap kepatuhan wajib pajak UMKM di Kota Yogyakarta, dan mengindikasikan bahwa Pemahaman Perpajakan yang semakin baik maka Kepatuhan Wajib Pajak akan semakin baik pula. Beberapa penelitian terdahulu yang 
menguji kualitas pelayanan telah dilakukan oleh Hardiningsih dan Yulianawati (2011), dan Saputra (2015) mengatakan bahwa kualitas layanan signifikan berpengaruh positif terhadap kemauan membayar pajak. Penelitian selanjutnya yang dilakukan oleh Cahyadi dan Jati (2016) menemukan bukti bahwa akuntabilitas pelayanan publik berpengaruh positif pada kepatuhan wajib pajak, ini dikarenakan apabila petugas pajak bisa memberikan pelayanan publik secara transparan dan terbuka, hal tersebut dapat mempengaruhi sumber potensi penerimaannya.

Atas dasar ketidakkonsistenan hasil temuan beberapa peneliti sebelumnya, maka peneliti tertarik untuk meneliti kembali penelitian yang dilakukan oleh Razak dan Adafula (2013) dimana variabel yang ditelitinya adalah pemahaman perpajakan dan persepsi atas akuntabilitas. Peneliti menambahkan dua variabel yang digunakan oleh Saputra (2015) dan Cahyadi dan Jati (2016) yaitu kesadaran wajib pajak dan sanksi pajak.

\section{LITERATURE REVIEW DAN PENGEMBANGAN HIPOTESIS Theory Of Planned Behavior (TPB)}

Teori perilaku terencana atau TPB (Theory of Planned Behavior) merupakan pengembangan lebih lanjut dari teori perilaku beralasan (Theory of Reasoned Action) (Ajzen, 1991). Penekanan utama pada TRA didasarkan pada perilaku sukarela. Namun perilaku tersebut nampak tidak sukarela dan terkendali. Hal ini menyebabkan dimasukkannya kontrol perilaku yang dirasakan. Inklusi semacam itu menyebabkan adanya TPB (Ameyaw et al, 2016). TPB merupakan kerangka berpikir konseptual yang bertujuan untuk menjelaskan determinan perilaku tertentu (Ajzen, 1991). TPB memprediksi bahwa perilaku bisa disengaja dan direncanakan, serta menegaskan bahwa niat individu untuk keluar dengan perilaku adalah prediktor terbaik mengenai apakah perilaku semacam itu benarbenar dilakukan atau tidak. Prediktor perilaku terbaik adalah perilaku yang ditunjukkan seseorang (Ameyaw et al, 2016).

Faktor utama dalam teori TPB (Theory of Planned Behavior) ini adalah niat seseorang individu untuk melaksanakan perilaku dimana niat diindikasikan dengan seberapa kuat keinginan seseorang untuk mencoba atau seberapa besar usaha yang dilakukan untuk melaksanakan perilaku tersebut (Kurniawati dan Toly, 2014). Umumnya, semakin besar niat seseorang untuk berperilaku, semakin besar pula kemungkinan perilaku tersebut dicapai atau dilaksanakan (Ajzen, 1991). Seseorang dapat saja memiliki berbagai macam keyakinan terhadap suatu perilaku, namun ketika dihadapkan pada suatu kejadian tertentu, hanya sedikit dari keyakinan tersebut yang timbul untuk mempengaruhi perilaku. Sedikit keyakinan inilah yang menonjol dalam mempengaruhi perilaku individu (Ajzen 1991). Keyakinan yang menonjol ini dijelaskan oleh Kurniawati dan Toly (2014) mengenai Theory of Planned Behavior yang terbagi menjadi tiga macam alasan dan dapat mempengaruhi tindakan yang akan diambil oleh individu yaitu:

1. Behavioral Belief, adalah keyakinan akan hasil dari suatu perilaku dan evaluasi atau penilaian terhadap hasil perilaku tersebut. Keyakinan dan evaluasi atau penilaian terhadap hasil dari suatu perilaku tersebut kemudian akan membentuk variabel sikap (attitude).

2. Normative Belief, yaitu keyakinan individu terhadap harapan normatif individu atau orang lain yang menjadi referensi seperti keluarga, teman, atasan, atau konsultan pajak untuk menyetujui atau menolak melakukan suatu perilaku yang diberikan. Hal ini akan membentuk variabel norma subjektif (subjectif norm).

3. Control Belief, yaitu keyakinan individu yang didasarkan pada pengalaman masa lalu 
dengan perilaku, serta faktor atau hal-hal yang mendukung atau menghambat persepsinya atas perilaku. Keyakinan ini membentuk variabel kontrol perilaku yang dipersepsikan atas perilaku. Keyakinan ini membentuk variabel kontrol yang dipersepsikan (perceived behavioral control).

\section{Hipotesis \\ Pemahaman Peraturan Perpajakan dan Kepatuhan Wajib Pajak}

Theory Of Planned Behavior menjelaskan bahwa niat merupakan faktor motivasi dari dalam diri seseorang yang dapat mempengaruhi perilaku untuk melakukan suatu tindakan tertentu. Salah satu komponen yang dapat mempengaruhi niat seseorang adalah kontrol prilaku yang dipersepsikan menjelaskan mengenai adanya dukungan dan rintangan untuk menentukan suatu perilaku individu. Berdasarkan pandangan tersebut memunculkan sebuah pemikiran bahwa WP yang paham mengenai peraturan perpajakan maka akan memudahkan atau menjadi hal pendukung bagi WP untuk mematuhi peraturan perpajakan.

Pemahaman wajib pajak mengenai peraturan perpajakan dapat mempengaruhi kepatuhan wajib pajak melalui adanya perilaku wajib pajak yaitu apabila Wajib Pajak yang tidak memahami peraturan perpajakan secara jelas cenderung akan menjadi wajib pajak yang tidak taat. Hal tersebut dikarenakan kurangnya pemahaman mengenai peraturan perpajakan, maka wajib pajak tidak mengetahui mengenai sanksi yang akan diterima bila melalaikan kewajiban perpajakan mereka dimana wajib pajak yang benar-benar paham, mereka akan tahu sanksi adminstrasi dan sanksi pidana sehubungan dengan SPT dan NPWP (Hardiningsih dan Yulianawati, 2011). Beberapa penelitian terdahulu (Dahruji, 2011; Imaniati, 2016; dan Astina dan Setiawan, 2018) telah memberikan kesimpulan hasil penelitian yang sama dimana pemahaman peraturan perpajakan yang dimiliki oleh wajib pajak berpengaruh positif dan signifikan terhadap kepatuhan wajib pajak sehingga hipotesis pertama yang diajukan dalam penelitian ini adalah:

\section{$\mathbf{H}_{1}$ : Pemahaman peraturan perpajakan berpengaruh positif terhadap kepatuhan wajib pajak}

\section{Akuntabilitas Pemerintah dan Kepatuhan Wajib Pajak}

Akuntabilitas pemerintah didasari oleh Theory of Planned Behavior. Teori ini menjelaskan beberapa komponen yang mempengaruhi perilaku individu, salah satunya adalah norma subjektif. Hal tersebut berpandangan bahwa ketika individu secara sukarela mematuhi kewajiban pajak mereka, mereka mengharapkan kontribusi atau hasil dari pajak yang telah mereka bayar. Berdasarkan penjelasan tersebut memunculkan sebuah pemikiran bahwa adanya transparansi dan pertanggungjawaban pemerintah dalam mengelola dana publik serta adanya feedback dari membayar pajak, maka wajib pajak yakin pajak yang dibayarkan dikelola dengan jelas serta manfaat yang didapatkan dari dana publik akan menjadikan wajib pajak termotivasi untuk membayar pajak.

Hal tersebut dapat ditarik kesimpulan bahwa pejabat pemerintah tidak hanya bertanggungjawab kepada otoritas yang lebih tinggi dalam rantai komando institusional, tetapi juga bertanggungjawab kepada masyarakat umum, lembaga swadaya masyarakat, media masa, dan banyak stakeholder lain. Oleh karena itu pelaporan belanja pajak pada APBN harus mudah dipahami, terbuka, dan akuntabel. Dengan demikian masyarakat umum bisa memperoleh informasi yang cukup tentang alokasi belanja dari sumber penerimaan pajak. Dengan akuntabilitas pemerintah yang bagus diharapkan akan berpengaruh terhadap kepatuhan wajib pajak (Latifah, 2013). Beberapa penelitian terdahulu 
telah memberikan hasil penelitian yang konsisten dimana Hardiningsih dan Yulianawati (2011); Saputra, (2015), dan Cahyadi dan Jati (2016) menyimpulkan akuntabilitas pelayanan publik berpengaruh positif terhadap kepatuhan WP sehingga hipotesis kedua yang diajukan adalah:

\section{$\mathbf{H}_{2}$ : Akuntabilitas pemerintah berpengaruh positif terhadap kepatuhan wajib pajak}

\section{Kesadaran Wajib Pajak dan Kepatuhan Wajib Pajak}

Behavorial belief menjadi faktor penentu niat yang dijelaskan di dalam Theory of Planned Behavior. Behavorial belief menjelaskan bahwa perilaku wajib pajak didasari adanya keyakinan mengenai hasil yang akan diperoleh dari tindakan individu tersebut. Keyakinan individu berkaitan dengan kesadaran wajib pajak. Berdasarkan pandangan tersebut memunculkan sebuah pemikiran bahwa WP mempunyai keyakinan mengenai pajak yang dibayarkan akan memberikan kontribusi nyata bagi dirinya sehingga wajib pajak termotivasi untuk patuh terhadap peraturan perpajakan.

Kesadaran wajib pajak memiliki arti bahwa adanya keyakinan yang timbul dari dalam diri wajib pajak untuk membayar pajaknya secara sukarela dan tidak adanya pengaruh dari pihak manapun dalam menentukan keputusannya. Hal tersebut dapat disimpulkan bahwa semakin tinggi tingkat kesadaran wajib pajak maka wajib pajak mempunyai pemahaman dan tingkat kesadaran untuk melaksanakan kewajibanya semakin baik sehingga wajib pajak secara sukarelauntuk mematuhi peraturan perpajakan. Maka dari itu adanya tingkat kesadaran yang tinggi dari wajib pajak dapat meningkatkan kepatuhan wajib pajak.

Beberapa penelitian sebelumnya yang telah dilakukan dinataranya adalah Hardiningsih dan Yulianawati (2011); Dahruji (2011); Saputra (2015); Cahyadi dan Jati (2016) dan Astina dan Setiawan (2018)menemukan bukti bahwa kesadaran membayar pajak signifikan berpengaruh positif terhadap kemauan membayar pajak sehingga hipotesis ketiga yang diajukan adalah:

\section{$\mathbf{H}_{3}$ : Kesadaran wajib pajak berpengaruh positif terhadap kepatuhan wajib pajak}

\section{Pengaruh Sanksi Pajak dan Kepatuhan Wajib Pajak}

Salah satu komponen yang terdapat di dalam Theory of Planned Behavior yaitu Persepsi kontrol keperilakuan yang menjelaskan bahwa persepsi individu mengacu pada adanya kemudahan atau kesulian dalam melakukan suatu tindakan serta diasumsikan untuk mencerminkan pengalaman masalalu serta antisipasi terhadap hambatan dan rintangan. Adanya penjelasan tersebut memunculkan sebuah pemikiran bahwa adanya pemberian sanksi yang tegas dari Direktorat Jendral Pajak akan menjadikan hambatan untuk melanggar aturan perpajakan sehingga memicu timbulnya motivasi dari wajib pajak untuk mematuhi peraturan perpajakan. Sanksi pajak memiliki peran penting guna memberikan pelajaran bagi pelanggar pajak agar tidak meremehkan peraturan perpajakan. Pemerintah diharapkan memberikan sanksi yang tegas bagi wajib pajak yang melanggar peraturan perpajakan. Hal tersebut bertujuan untuk memberikan efek jera bagi wajib pajak yang melanggar, sehingga wajib pajak dapat termotivasi untuk menaati aturan perpajakan.

Beberapa hasil penelitian terdahulu diantaranya penelitian Saputra (2015); Cahyadi dan Jati (2016); Khasanah (2016) menemukan bukti empiris sanksi pajak berpengaruh positif terhadap kepatuhan yang berarti semakin tinggi sanksi pajak yang diberikan maka akan membuat wajib pajak semakin patuh. Berdasarkan beberapa hasil penelitian terdahulu, hipotesis yang keempat yang diajukan adalah :

\section{$\mathbf{H}_{4}$ : Sanksi pajak berpengaruh positif terhadap kepatuhan wajib pajak}




\section{METODE PENELITIAN Jenis Penelitian}

Jenis penelitian yang digunakan dalam penelitian ini adalah penlitian kuantitatif dengan metode survey. Penelitian kuantitatif dengan metode survey adalah penelitian yang dilakukan pada populasi besar ataupun kecil data yang dipelajari adalah data dari sampel yang diambil dari populasi tersebut (Sugiyono, 2019). Jenis data yang digunakan dalam penelitian ini adalah data primer. Data dikumpulkan melalui metode angket, yaitu menyebar daftar pertanyaan (kuisoner).

\section{Definisi Operasional dan Pengukuran Variabel Variabel Dependen Kepatuhan Wajib Pajak}

Kepatuhan wajib pajak adalah suatu keadaan dimana wajib pajak telah memenuhi semua kewajiban perpajakannya, atau suatu tindakan yang dilakukan oleh wajib pajak dalam memenuhi kewajiban perpajakannya tepat waktu serta patuh terhadap peraturan dan ketentuan yang telah ditetapkan oleh pemerintah (Pratama, 2012).

Indikator variabel kepatuhan wajib pajak dirujuk pada hasil penelitian Mutia (2014) dan dikembangkan oleh Siahaan (2019) yaitu, mendaftarkan diri secara sukarela untuk mendapatkan NPWP, mengisi dan melaporkan SPT dengan benar, lengkap, jelas sesuai dengan ketentuan berlaku, dan tepat waktu, serta melaporkan kewajiban perpajakan dalam bentuk SPT, kemudian dikembangkan menjadi 8 (delapan) item pernyataan dan diukur menggunakan skala likert 1 sampai dengan 5 serta menggunakan kriteria tertentu dalam penilaiannya. Dimana dalam setiap item pernyataan itu jika responden memberikan nilai satu maka kepatuhan wajib pajak rendah, sedangkan jika responden memberikan nilai lima maka kepatuhan wajib pajak tinggi.

\section{Variabel Independen \\ Pemahaman Peraturan Perpajakan}

Indikator variabel pemahaman peraraturan perpajakan dirujuk pada hasil penelitian Razak dan Adafula (2013) yaitu pemahaman wajib pajak mengenai peraturan perpajakan, dan hukum pajak penghasilan ditulis menggunakan bahasa yang sulit dimengerti, dan kemudian dikembangkan menjadi tiga item pernyataan dan diukur menggunakan skala likert 1 (pemahaman wajib pajak mengenai peraturan perpajakan sangat rendah) sampai dengan 5 (pemahaman wajib pajak mengenai peraturan perpajakan sangat bagus).

\section{Akuntabilitas Pemerintah}

Indikator variabel persepsi atas akuntabilitas dirujuk pada hasil penelitian Razak dan Adafula (2013) yaitu, persepsi wajib pajak mengenai transparansi dan akuntabilitas dari Direktorat Jendral Pajak terhadap penggunaan dana publik yang dikelola, tingkat kepercayaan wajib pajak terhadap pihak pajak dan manfaat yang didapatkan dari membayar pajak, kemudian dikembangkan menjadi 10 (sepuluh) item pernyataan dan dinilai menggunakaan skala likert 1 (jika responden memberikan nilai satu maka persepsi wajib pajak atas akuntabilitas pemerintah rendah) sampai dengan 5 (persepsi wajib pajak atas akuntabilitas pemerintah tinggi).

\section{Kesadaran Wajib Pajak}

Indikator variabel kesadaran wajib pajak dirujuk pada hasil penelitian Mutia (2014) 
dan dikembangkan oleh Siahaan (2019) yaitu, menghitung pajak terhutang, mengisi dan melaporkan SPT dengan jujur, paham akan adanya aturan-aturan perpajakan atau kosekuensi pelanggaran serta paham akan pentingnya membayar pajak dan melaporkan SPT sesuai dengan ketentuan. Kemudian dikembangkan menjadi delapan item pernyataan dan dinilai menggunakan skala likert 1 (kesadaran wajib pajak rendah) sampai dengan 5 (kesadaran wajib pajak tinggi).

\section{Sanksi Pajak}

Indikator variabel sanksi dirujuk pada hasil penelitian Mutia (2014) dan dikembangkan oleh Siahaan (2019) yaitu, penerapan sanksi yang tegas, sanksi diatur dalam UU ketentuan dan tata cara perpajakan, penerapan sanksi menurut tingkat pelanggarannya dan penerapan sanksi pidana menurut jenis pelanggarannya, kemudian dikembangkan menjadi 8 item pernyataan dan dinilai menggunakan skala likert 1 (wajib pajak sangat sering mendapatkan sanksi) sampai dengan 5 (wajib pajak tidak pernah mendapatkan sanksi).

\section{Populasi dan Sampel}

Populasi adalah keseluruhan kelompok orang, kejadian atau hal mana yang ingin peneliti investigasi. Sedangkan sampel (sample) adalah subkelompok atau sebagian dari suatu populasi (Sekaran dan Bougie, 2006). Populasi dalam penelitian ini adalah wajib pajak orang pribadi UMKM di Kota Bengkulu. Pengambilan sampel dalam penelitian ini menggunakan Purposive sampling yaitu salah satu teknik sampling non random sampling dimana peneliti menentukan pengambilan sampel dengan cara menetapkan kriteria khusus yang sesuai dengan tujuan penelitian. Kriteria populasi penelitian ini adalah wajib pajak perorangan yang memiliki Usaha Mikro, Kecil, dan Menengah yang bergerak dibidang perdagangan, industri dan aneka jasa yang usahanya berada di wilayah Kota Bengkulu, dan lama memiliki usahanya minimal satu tahun.

\section{Tabel 1}

\section{Jumlah Populasi Penelitian}

\begin{tabular}{ccccc}
\hline Jenis usaha & Perdagangan & Industri & Aneka jasa & Total WP \\
\hline WP OP & 2.866 & 508 & 508 & 3.882 \\
\hline \multicolumn{4}{l}{ Sumber : Diolah oleh Dinas Koperasi } & UMKM Perindustrian dan Perdagangan Kota Bengkulu tahun 2019
\end{tabular}

Penjumlahan sampel dalam penelitian ini menggunakan teknik Slovin (Setiawan, 2013) sehingga jumlah responden yang representatif adalah 100 responden wajib pajak orang pribadi.

\section{Metode Pengumpulan Data}

Metode pengumpulan data pada penelitian ini menggunakan metode survey melalui kuisoner. Metode survey merupakan metode pengumpulan data primer yang menggunakan pernyataan lisan dan tertulis, sedangkan kuesioner merupakan suatu cara pengumpulan data dengan menyebarkan daftar pernyataan kepada responden dengan harapan mereka akan memberikan respon terhadap daftar pernyataan tersebut.

Kuesioner dalam penelitian ini dibagikan secara personal (personality administered quenstionnarires). Penyebaran kuesioner dilakukan dengan mendatangi satu persatu calon responden, mengecek apakah calon memenuhi persyaratan sebagai calon responden, lalu menyatakan kesediaan untuk mengisi kuesioner dan menunggu responden untuk mengisi kuesioner. Kuesioner dalam penelilitian ini disusun berdasarkan variabel yang akan diuji, 
yaitu, pemahaman perpajakan, akuntabilitas pemerintah, kesadaran wajib pajak, sanksi pajak, serta kepatuhan wajib pajak.

\section{Statistik Deskriptif}

Statistik deskriptif dalam penelitian pada dasarnya merupakan proses transformasi dalam bentuk tabulasi sehingga mudah untuk dipahami dan diinterprestasikan. Analisis statistik deskriptif dalam penelitian ini meliputi rata- rata (mean), standar deviasi, nilai minimum dan nilai maksimum.

\section{Uji Kualitas Data \\ Uji Validitas}

Uji validitas dalam penelitian ini adalah menggunakan CFA (Confirmatory Factor Analysis). Untuk pengujian CFA, Kaiser Mayer Olkin (KMO) dan barlett's untuk korelasi antara variabel yang diinginkan adalah diatas 0,05 dan tingkat signifikansi penelitian adalah dibawah 0,05 (Ghozali, 2013).

\section{Uji Reabilitas}

Pengukuran reabilitas dalam penelitian ini menggunakan uji statistik Croncbach Alpha $(\alpha)>0,70$ (Ghozali, 2013).

\section{Uji Hipotesis}

Analisis yang digunakan dalam penelitian ini adalah analisis regresi linier berganda. Tujuannya untuk mengetahui pengaruh pemahaman peraturan perpajakan, akuntabilitas pemerintah, kesadaran wajib pajak dan sanksi pajak terhadap kepatuahan wajib pajak. Rumus yang digunakan adalah sebagai berikut:

\section{Keterangan :}

$$
Y=\alpha+\beta_{1} X_{1}+\beta_{2} X_{2}+\beta_{3} X_{3}+\beta_{4} X_{4}+\varepsilon
$$

\begin{tabular}{|c|c|}
\hline Y & $=$ kepatuhan wajib pajak \\
\hline$\alpha$ & $=$ konstanta \\
\hline$\beta_{1}, \beta_{2}, \beta_{3}, \beta_{4}$ & $=$ koefesiensi regresi \\
\hline $\mathrm{X}_{1}$ & $=$ pemahaman peraturan perpajakan \\
\hline $\mathrm{X}_{2}$ & $=$ Akuntabilitas pemerintah \\
\hline $\mathrm{X}_{3}$ & $=$ kesadaran wajib pajak \\
\hline $\mathrm{X}_{4}$ & $=$ sanksi pajak \\
\hline & = faktor pengganggu (disturbance err \\
\hline
\end{tabular}

\section{HASIL PENELITIAN \\ Deskripsi Data}

Data dalam penelitian ini didapatkan dari Kantor Dinas Koperasi UMKM Perindustrian dan Perdagangan Kota Bengkulu yang memiliki jumlah sebanyak 3882 wajib pajak orang pribadi yang memiliki jenis usaha perdagangan, industri dan jasa. Dari jumlah tersebut dilakukan penghitungan menggunakan rumus slovin untuk menentukan jumlah sampel yang ditargetkan, dan hasil yang didapatkan sebanyak 98 wajib pajak atau responden. Dari penghitungan slovin yang didapatkan dilakukan penambahan sampel dalam penyebaran kuisoner yaitu sebanyak 32 kuisoner yang bertujuan untuk mengantsipasi tidak kembalinya kuisoner atau tidak lengkapnya pengisian kuisoner yang menyebabkan tidak tercapainya jumlah sampel yang ditargetkan. selanjutnya dilakukan penyebaran 
kuisoner secara acak dan langsung kepada 130 responden yang memiliki usaha di Kota Bengkulu. Secara lebih rinci tingkat pengembalian kuesioner dapat dilihat pada tabel 1 berikut:

\section{Tabel 2}

\section{Tingkat Pengambilan Kuisoner}

\begin{tabular}{llcc}
\hline No & Keterangan & Jumlah & Persentase \\
\hline 1 & Kuisoner yang disebar & 130 kuisoner & $100 \%$ \\
\hline 2 & Kuisoner yang tidak dikembalikan & (20 kuisoner) & $15,3 \%$ \\
\hline 3 & Kuisoner yang dikembalikan & 110 kuisoner & $84,7 \%$ \\
\hline 4 & Kuisoner yang tidak dapat digunakan & (8 kuisoner) & $6,1 \%$ \\
\hline 5 & Kuisoner yang dapat digunakan & 102 kuisoner & $78,4 \%$ \\
\hline Sumber: Data Primer, diolab 2020 & &
\end{tabular}

\section{Statistik Deskriptif}

\section{Tabel 3}

\section{Statistik Deskriptif}

\begin{tabular}{|c|c|c|c|c|c|c|c|c|}
\hline \multirow[t]{2}{*}{ Variabel } & \multirow[t]{2}{*}{$\mathrm{N}$} & \multicolumn{2}{|c|}{ Kisaran Teoritis } & \multirow{2}{*}{$\begin{array}{c}\text { Rata- } \\
\text { rata } \\
\text { Teoriitis }\end{array}$} & \multicolumn{2}{|c|}{ Kisaran Aktual } & \multirow{2}{*}{$\begin{array}{c}\text { Rata- } \\
\text { rata } \\
\text { Aktual }\end{array}$} & \multirow{2}{*}{$\begin{array}{l}\text { Standar } \\
\text { Deviasi }\end{array}$} \\
\hline & & Min & Maks & & Min & Maks & & \\
\hline $\begin{array}{l}\text { Kepatuhan } \\
\text { Wajib Pajak }\end{array}$ & 102 & 8 & 40 & 24 & 25 & 40 & 33,862 & 3,920 \\
\hline $\begin{array}{l}\text { Pemahaman } \\
\text { Perpajakan }\end{array}$ & 102 & 3 & 15 & 9 & 3 & 11 & 5,441 & 1,799 \\
\hline Akuntabilitas & 102 & 10 & 50 & 30 & 10 & 40 & 29,568 & 5,254 \\
\hline $\begin{array}{l}\text { Kesadaran } \\
\text { Wajib Pajak }\end{array}$ & 102 & 8 & 40 & 24 & 20 & 40 & 33,421 & 3,792 \\
\hline Sanksi Pajak & 102 & 8 & 40 & 24 & 23 & 40 & 35,049 & 3,395 \\
\hline
\end{tabular}

Sumber: Data Primer, diolah 2020

Variabel kepatuhan wajib pajak memiliki nilai rata-rata teoritis sebesar 24, sedangkan untuk kisaran aktualnya sebesar 33,862. Hal ini mengindikasikan bahwa mayoritas responden menjawab pada skala 4 (setuju) dan menganggap bahwa mendaftaran diri secara sukarela untuk mendapatkan NPWP, membayar pajak terutang dan melaporkan SPTnya sesuai dengan aturan perpajakan yang berlaku itu adalah suatu bentuk kewajiban bagi setiap masyarakat.

Variabel pemahaman peraturan perpajakan mempunyai nilai rata-rata teoritis sebesar 9 sedangkan nilai rata-rata aktualnya sebesar 5,441. Hal ini mengindikasikan bahwa mayoritas responden menjawab pada skala 2 (rendah/setuju) yang berarti bahwa responden memiliki pemahaman peraturan perpajakan masih rendah dikarenakan responden menganggap penulisan undang- undang pajak penghasilan sulit untuk dipahami, sehingga menjadikan Wajib Pajak Orang Pribadi yang memiliki usaha di Kota Bengkulu memiliki pemahaman mengenai peraturan perpajakan masih rendah.

Variabel akuntabilitas pemerintah mempunyai nilai rata-rata teoritis 30 dan rata-rata aktualnya sebesar 29,658. Hal ini mengindikasikan bahwa mayoritas responden menjawab pada skala 3 (sedang/kadang-kadang) yang berarti bahwa responden menilai tingkat tranparasi dan akuntabilitas pemerintah masih kurang dan responden memiliki tingkat kepercayaan yang sedang (tidak terlalu tinggi dan juga tidak terlalu rendah) dikarenakan 
manfaat yang didapatkan dirasanya masih kurang. Maka dari itu Wajib Pajak Orang Pribadi yang memiliki usaha di Kota Bengkulu menilai bahwa akuntabilitas pemerintah masih rendah.

Variabel kesadaran wajib pajak mempunyai nilai rata-rata teoritis 24, sedangkan rata-rata pada kisaran aktualnya sebesar 33,421. Hal ini mengindikasikan bahwa mayoritas responden menjawab pada skala 4 (setuju) yang berarti bahwa responden telah membayar pajaknya dengan jujur, tepat waktu dan sesuai peraturan perpajakan yang telah ditentukan.

Variabel sanksi pajak mempunyai nilai rata-rata teoritis 24, sedangkan rata-rata pada kisaran aktualnya sebesar 35,409. Hal ini mengindikasikan bahwa mayoritas responden menjawab di skala 5 (tidak pernah) yang berarti bahwa Wajib Pajak Orang Pribadi yang memiliki usaha di Kota Bengkulu tidak pernah mendapatkan sanksi atau denda dari pihak pajak.

\section{Hasil Uji Kualitas Data}

\section{Uji Validitas}

\section{Tabel 4}

\section{Hasil Uji Validitas}

\begin{tabular}{clccc}
\hline No & \multicolumn{1}{c}{ Variabel } & KMO & Sig & Keterangan \\
\hline 1 & Pemahaman peraturan perpajakan & 0,667 & 0,000 & Valid \\
\hline 2 & Akuntabilitas pemerintah & 0,698 & 0,000 & Valid \\
\hline 3 & Kesadaran wajib pajak & 0,808 & 0,000 & Valid \\
\hline 4 & Sanksi pajak & 0,726 & 0,000 & Valid \\
\hline 5 & Kepatuhan wajib pajak & 0,793 & 0,000 & Valid \\
\hline
\end{tabular}

Sumber: Data Primer, diolah 2020

Berdasarkan tabel 3 di atas menunjukan bahwa hasil pengujian validitas pada semua variabel tersebut lebih dari 0,05 dan memiliki nilai sig sebesar 0,000 yaitu kurang dari 0,05 , sehingga dapat disimpulkan bahwa semua variabel dalam penelitian ini sudah valid dan dapat dilanjutkan untuk digunakan pada pengujian selanjutnya.

\section{Hasil Uji Reabilitas}

\section{Tabel 5}

\section{Uji Reabilitas}

\begin{tabular}{llcr}
\hline No & Variabel & Croncbach Alpha $(\alpha)$ & Keterangan \\
\hline 2 & Pemahanaman peraturan perpajakan & 0,711 & Reliabel \\
\hline 3 & Akuntabilitas pemerintah & 0,743 & Reliabel \\
\hline 4 & Kesadaran wajib pajak & 0,869 & Reliabel \\
\hline 5 & Sanksi pajak & 0,791 & Reliabel \\
\hline 6 & Kepatuhan wajib pajak & 0,756 & Reliabel \\
\hline Sumber: Data Primer, diolah 2020 & &
\end{tabular}

Berdasarkan hasil pengujian reabilitas pada tabel 4 diatas, nilai Croncbach Alpha $(\alpha)$ untuk semua variabel memiliki nilai Croncbach Alpha $(\alpha)$ lebih dari 0,70, sehingga dapat disimpulkan bahwa pernyataan untuk masing-masing variabel dapat dikatakan reliabel atau handal. 


\section{Hasil Pengujian Hipotesis \\ Tabel 6 \\ Hasil Pengujian Hipotesis}

\begin{tabular}{|c|c|c|c|c|}
\hline Variabel & Coefficients & t hitung & Sig & $\begin{array}{c}\text { Keteranga } \\
\mathrm{n}\end{array}$ \\
\hline Pemahaman peraturan perpajakan & 0,134 & 1,445 & 0,152 & Ditolak \\
\hline Akuntabilitas pemerintah & 0,020 & 0,217 & 0,829 & Ditolak \\
\hline Kesadaran wajib pajak & 0,220 & 2,379 & 0,019 & Diterima \\
\hline Sanksi pajak & 0,300 & 3,229 & 0,002 & Diterima \\
\hline R Square & \multicolumn{4}{|c|}{0,178} \\
\hline Adjusted $\mathrm{R}^{2}$ & \multicolumn{4}{|c|}{0,144} \\
\hline $\mathrm{F}$ & \multicolumn{4}{|c|}{5,257} \\
\hline Sig & \multicolumn{4}{|c|}{0,001} \\
\hline
\end{tabular}

Sumber : Data Primer, diolah, 2020

Berdasarkan hasil regresi pada tabel di atas, menunjukan bahwa nilai $\mathrm{F}$ hitung sebesar 5,257 dengan menggunakan batas signifikansi 0,001, sehingga dapat disimpulkan bahwa model dalam penelitian ini fit atau layak untuk digunakan dikarenakan nilai signifikansi dalam penelitian ini lebih kecil dari 0,05. Kemudian dilihat dari nilai Adjusted $\mathrm{R}^{2}$ sebesar 0,144 yang menunjukan bahwa sebesar 14,4\% variabel kepatuhan wajib pajak dapat dijelaskan oleh variabel pemahaman peraturan perpajakan, akuntabilitas pemerintah, kesadaran wajib pajak serta sanksi pajak sedangkan sisanya 85,6 \% dijelaskan oleh variabel lain yang tidak dijelaskan dalam penelitian ini.

\section{Pengaruh Pemahaman Peraturan Perpajakan terhadap Kepatuhan Wajib Pajak}

Berdasarkan hasil pengujian pada hipotesis pertama diketahui bahwa variabel pemahaman peraturan perpajakan tidak berpengaruh terhadap kepatuhan wajib pajak. Hal ini berarti pemahaman peraturan perpajakan tidak menjadi faktor yang mempengaruhi kepatuhan wajib pajak terhadap kepatuhan wajib pajak. Dengan demikian dapat disimpulkan bahwa hipotesis 1 yang menyatakan bahwa pemahaman perpajakan berpengaruh positif terhadap kepatuhan wajib pajak, "ditolak".

Variabel pemahaman peraturan perpajakan dapat dihubungkan menggunakan TPB (Theory Of Planned Behavioural) yaitu (control belief) yang menjelaskan bahwa perilaku wajib pajak dipengaruhi adanya hambatan atau dukungan untuk memahami peraturan perpajakan yang dirasanya sulit atau mudah untuk dimengerti, sehingga akan membentuk perilaku wajib pajak dalam menentukan keputusannya. Dalam penelitian ini, Wajib Pajak Orang Pribadi yang memiliki usaha di Kota Bengkulu mempunyai pemahaman mengenai peraturan perpajakan yang masih rendah dikarenakan wajib pajak memiliki anggapan bahwa penulisan hukum pajak penghasilan menggunakan bahasa yang sulit untuk dipahami, sehingga menjadikan hambatan bagi wajib pajak untuk memahami peraturan perpajakan dengan baik. Adanya hambatan tersebut menjadikan pemahaman wajib pajak yang rendah sehingga menjadikan wajib pajak tidak patuh terhadap peraturan perpajakan. Penelitian ini tidak mampu menjelaskan Theory Of Planned Behavioural dalam menjelaskan variabel pemahaman peraturan perpajakan terhadap kepatuhan wajib pajak.

Hasil penelitian ini tidak sejalan dengan hasil penelitan dari Dahruji (2011), Razak dan Adafula (2013), Imaniati (2016), Khasanah (2016), Astina dan Setiawan (2018) yang 
mengatakan bahwa pemahaman perpajakan berpengaruh positif terhadap kepatuhan wajib pajak.

\section{Pengaruh Akuntabilitas Pemerintah terhadap Kepatuhan Wajib Pajak}

Berdasarkan hasil pengujian pada hipotesis kedua diketahui bahwa persepsi wajib pajak atas akuntabilitas pemerintah tidak berpengaruh terhadap kepatuhan wajib pajak. Hal ini berarti akuntabilitas pemerintah tidak menjadi faktor yang mempengaruhi kepatuhan wajib pajak terhadap kepatuhan wajib pajak. Dengan demikian hipotesis 2 yang menyatakan bahwa akuntabilitas pemerintah berpengaruh positif terhadap kepatuhan wajib pajak "ditolak".

Variabel akuntabilitas pemerintah dapat dihubungkan dengan Theory Of Planned Behavioural yaitu (normatif belief) yang menjelaskan bahwa perilaku wajib pajak dapat dipengaruhi oleh pertanggungjawaban dan keterbukaan pihak pajak dalam mengelola dana publik serta memberikan feedback dari dana publik tersebut, sehingga akan memberikan motivasi bagi wajib pajak untuk memenuhi kewajiban perpajakannya. Dalam penelitian ini Wajib Pajak Orang Pribadi yang memiliki usaha di Kota Bengkulu mempunyai tingkat kepercayaan yang rendah terhadap pemerintah. Hal tersebut dikarenakan wajib pajak beranggapan bahwa pemerintah kurang bertanggungjawab dan tidak adanya keterbukaan mengenai dana publik yang dikelola, sehingga wajib pajak kurang mempercayai pihak pajak atas penggunaan dana publik. Tingkat kepercayaan yang rendah menjadikan wajib pajak ragu untuk memenuhi kewajiban perpajakannya. Penelitian ini tidak mampu membuktikan Theory Of Planned Behavioural dalam menjelaskan variabel akuntabilitas pemerintah terhadap kepatuhan wajib pajak.

Hasil penelitian ini tidak sejalan penelitian Saputra (2015), Cahyadi dan Jati (2016), Khasanah (2016), Astina dan Setiawan (2018) yang menyimpulkana pelayanan publik/ akuntabilitas pemerintah berpengaruh positif terhadap kepatuhan wajb pajak.

\section{Pengaruh Kesadaran Wajib Pajak terhadap Kepatuhan Wajib Pajak}

Berdasarkan hasil Pengujian hipotesis ketiga diketahui bahwa kesadaran wajib pajak berpengaruh positif terhadap kepatuhan wajib pajak. Hal ini berarti semakin tinggi kesadaran wajib pajak terhadap peraturan perpajakan maka akan semakin tinggi tingkat kepatuhan wajib pajak. Dengan demikian dapat disimpulkan bahwa hipotesis 3 yang menyatakan bahwa kesadaran wajib pajak berpengaruh positif terhadap kepatuhan wajib pajak " dapat diterima".

Variabel kesadaran wajib pajak dapat dihubungkan dengan Theory Of Planned Behavioural yaitu sikap yang menjelaskan bahwa perilaku wajib pajak berasal dari keyakinan wajib pajak akan hasil yang diperoleh dari membayar pajak, sehingga akan membentuk perilaku wajib pajak untuk menentukan keputusan kepatuhan dalam menjalankan kewajiban perpajakannya. Dalam penelitian ini Wajib Pajak Orang Pribadi yang memiliki usaha di Kota Bengkulu memiliki kesadaran bahwa pajak yang dibayarkan akan mendapat konstribusi dari pemerintah yang digunakan untuk pembagunan negara. Adanya kesadaran wajib pajak atas manfaat yang didapatkan setelah membayar pajak akan menjadikan wajib pajak termotivasi untuk memenuhi kewajibannya dalam membayar pajak. Penelitian ini mendukung Theory of Planned Behavioural dalam menjelaskan menjelaskan pengaruh kesadaran wajib pajak terhadap kepatuhan wajib pajak.

Hasil penelitian ini sejalan dengan penelitian Dahruji (2011), Saputra (2015), Cahyadi dan Jati (2016), dan Astina dan Setiawan (2018), yang menemukan bahwa 
kesadaran wajib pajak berpengaruh positif terhadap kepatuhan wajib pajak. Hal ini berarti bahwa kesadaran dari wajib pajak menjadikan faktor penentu untuk menentukan wajib pajak patuh dalam memenuhi kewajiban perpajakan.

\section{Pengaruh Sanksi Pajak terhadap Kepatuhan Wajib Pajak}

Berdasarkan hasil pengujian hipotesis keempat diketahui bahwa variabel sanksi pajak terbukti berpengaruh positif terhadap kepatuhan wajib pajak. Hal ini menunjukan bahwa semakin tegas pemberian sanksi yang diterapkan maka akan menjadikan wajib pajak semakin memenuhi kewajiban perpajakannya. Maka dapat ditarik kesimpulan bahwa semakin berat sanksi yang diterapkan oleh Direktorat Jendral Pajak maka akan menjadikan wajib pajak semakin patuh terhadap peraturan perpajakan. Dengan demikian dapat disimpulkan bahwa hipotesis 4 yang menyatakan bahwa sanksi pajak berpengaruh positif terhadap kepatuhan wajib pajak "dapat diterima".

Variabel sanksi pajak dapat dihubungkan menggunakan Theory Of Planned Behavioural yaitu (control belief) yang menjelaskan bahwa perilaku wajib pajak dipengaruhi adanya hambatan berupa sanksi dan denda yang diterapkan oleh Direktorat Jendral Pajak sehingga menjadikan wajib pajak merasa takut untuk melanggarnya. Dalam penelitian ini Wajib Pajak Orang Pribadi yang memiliki usaha di Kota Bengkulu hampir tidak pernah mendapatkan sanksi dari pihak pajak, hal tersebut dikarenakan wajib pajak mempunyai anggapan bahwa sanksi yang diterapkan oleh Dirjen Pajak menjadikan beban/hambatan yang dapat merugikan dirinya sendiri, sehingga penerapan sanksi yang berat untuk wajib pajak dapat menjadikan wajib pajak patuh terhadap peraturan perpajakan. Penelitian ini, mendukung Theory Of Planned Behavioural dalam menjelaskan variabel sanksi pajak terhadap kepatuhan wajib pajak.

Hasil penelitian ini sejalan dengan penelitian Saputra (2015), Cahyadi dan Jati (2016), Imaniati (2016), dan Khasanah (2016) yang mengatakan bahwa sanksi pajak berpengaruh signifikan terhadap kepatuhan wajib pajak. Wajib pajak akan semakin patuh jika sanksi yang diberlakukan semakin berat. Hal tersebut menandakan bahwa Wajib Pajak Orang Pribadi yang memiliki usaha di Kota Bengkulu merasa jera atas penerapan sanksi yang diberlakukan, sehingga menjadikan wajib pajak patuh dalam menjalankan kewajiban perpajakanya.

\section{KESIMPULAN}

\section{Kesimpulan}

Penelitian ini bertujuan untuk memperoleh bukti empiris tentang persepsi wajib pajak atas faktor-faktor yang mempengaruhi kepatuhan wajib pajak orang pribadi yang memiliki usaha di Kota Bengkulu. Berdasarkan hasil analisis data penelitian, maka dapat diambil kesimpulan sebagai berikut:

1. Hasil penelitian membuktikan pemahaman peraturan perpajakan tidak berpengaruh terhadap kepatuhan wajib pajak. Hal ini berarti bahwa pemahaman peraturan perpajakan tidak menjadi faktor yang mempengaruhi wajib pajak dalam memenuhi kewajiban perpajakannya.

2. Hasil penelitian membuktikan akuntabilitas pemerintah tidak berpengaruh terhadap kepatuhan wajib pajak. Hal ini berarti bahwa akuntabilitas pemerintah tidak menjadi faktor yang mempengaruhi wajib pajak dalam memenuhi kewajiban perpajakannya.

3. Hasil penelitian membuktikan kesadaran wajib pajak berpengaruh terhadap kepatuhan wajib pajak. Hal ini berarti bahwa semakin tinggi kesadaran wajib pajak maka akan 
menjadikan wajib pajak semakin patuh dalam memenuhi kewajiban perpajakannya.

4. Hasil penelitian membuktikan sanksi pajak berpengaruh terhadap kepatuhan wajib pajak. Hal ini berarti bahwa semakin berat sanksi yang diterapkan oleh Dirjen Pajak maka akan menjadikan wajib pajak semakin patuh dalam memenuhi kewajiban perpajakannya.

\section{Implikasi Penelitian}

1. Secara teoritis, penelitian ini dapat memberikan kontribusi bagi pengembangan theory of planned behavior (TPB) bahwa perilaku individu dapat mempengaruhi persepsi wajib pajak mengenai pemahaman peraturan perpajakan, akuntabilitas pemerintah, kesadaran wajib pajak serta sanksi pajak untuk menilai tingkat kepatuhan wajib pajak. perilaku wajib pajak didasari adanya persepsi atas manfaat yang didapatkan, keyakinan dalam diri dan hambatan atau dukungan untuk menjadi faktor pendorong terjadinya perilaku wajib pajak sehingga wajib pajak dapat menentukan keputusannya.

2 Secara praktis, penelitian ini dapat memberikan kontribusi bagi instansi perpajakan yaitu KPP Pratama Kota Bengkulu bahwa pemahaman peraturan perpajakan dan akuntabilitas pemerintah, dapat menjadikansalah satu faktor penyebab ketidakpatuhan wajib pajak, dan yang menjadi faktor penentu wajib pajak mau mematuhi perpajakan adalah dengan adanya kesadaran wajib pajak dan sanksi yang tegas dari pihak pajak. KPP Pratama Kota Bengkulu diharapkan mampu meyakinkan wajib pajak untuk memenuhi kewajiban membayar pajaknya.

\section{Keterbatasan}

1. Penelitian ini belum mampu membuktikan pemahaman peraturan perpajakan dan akuntabilitas pemerintah berpengaruh terhadap kepatuhan wajib pajak

2. Nilai Adjusted $\mathrm{R}$ square yang cukup rendah sehingga diduga ada variabel lain yang lebih mempengaruhi kepatuhan wajib pajak

\section{DAFTAR PUSTAKA}

\section{A. BUKU}

[1]. Ghozali, I. (2013). Aplikasi Analisis Multivariate dengan Program IBM SPSS 19 (5th ed.). Semarang: Badan Penerbit Universitas Diponegoro.

[2]. Sekaran, U. S., \& Bougie, R. J. (2016). Research Methods For Business: A Skill Building Approach (7th Edition). New York, United States: John Wiley \& Sons Inc

[3]. Sugiyono. (2019). Metode Penelitian Kuantitatif, Kualitatif, dan ReD (1st ed.). Bandung: Alfabeta.

\section{B. JURNAL}

[4]. Ajzen, I. (1991). The theory of planned behavior. Organizational Behavior And Human Decision Processes, 50, 179-211. https://doi.org/10.4135/9781446249215.n22

[5]. Ameyaw, B., Oppong, A., Aba Abruquah, L., \& Ashalley, E. (2016). Informal Sector Tax Compliance Issues and the Causality Nexus between Taxation and Economic Growth: Empirical Evidence from Ghana. Modern Economy, 07(12), 1478-1497. https://doi.org/10.4236/me.2016.712134

[6]. Astina, I. P. S., \& Setiawan, P. E. (2018). Pengaruh Pemahaman Peraturan Perpajakan, Kualitas Pelayanan Fiskus dan Kesadaran Wajib Pajak Terhadap Tingkat Kepatuhan WPOP. E-Jurnal Akuntansi Universitas Udayana, 23, 1-30. https://doi.org/10.24843/EJA.2018.v23.i01.p01 
[7]. Cahyadi, I. M. W., \& 2, I. K. J. (2016). Pengaruh Kesadaran, Sosialisasi, Akuntabilitas Pelayanan Publik Dan Sanksi Perpajakan Pada Kepatuhan Wajib Pajak Kendaraan Bermotor. E-Jurnal Akuntansi Universitas Udayana, 16(3), 2342-2373.

[8]. Dahruji. (2011). Pengaruh Perilaku Wajib Pajak Mengenai Tingkat Pemahaman Wajib Pajak Dan Kesadaran Wajib Pajak Terhadap Tingkat Kepatuhan Wajib Pajak Dalam Memenuhi Kewajiban Perpajakannya. Balance Economics, Bussiness, Management and Accounting Journal, 14(7), 75-91.

[9]. Dartini, G. A. A. S., \& Jati, I. K. (2016). Pemahaman Akuntansi, Transparasi, Dan Akuntabilitas Pada Kepatuhan Wajib Pajak Badan. E-Jurnal Akuntansi Universitas Udayana, 17(3), 2447-2473.

[10]. Hardiningsih, P., \& Yulianawati, N. (2011). Faktor-Faktor Yang Mempengaruhi Kemauan Membayar Pajak. Dinamika Kenangan Dan Perbankan, 3(1), 126-142. https://doi.org/ISSN: 1979-4878.

[11]. Imaniati, Z. Z., \& Isroah. (2016). Pengaruh Persepsi Wajib Pajak Tentang Penerapan PP No. 46 Tahun 2013, Pemahaman Perpajakan, Dan Sanksi Perpajakan Terhadap Kepatuhan Wajib Pajak Usaha Mikro, Kecil, Dan Menengah Di Kota Yogyakarta. Nominal, Barometer Riset Akuntansi Dan Manajemen, 5(2), 123-135. https://doi.org/10.21831/nominal.v5i2.11730

[12]. Kurniawati, M., \& Toly, A. A. (2014). Analisis Keadilan Pajak, Biaya Kepatuhan, dan Tarif Pajak Terhadap Persepsi Wajib Pajak Mengenai Penggelapan Pajak di Surabaya Barat. Tax \& Accounting Review, 4(2), 1-12.

[13]. Latifah. (2013). Pengaruh Kualitas Sistem Perpajakan, Resiko Audit, Akuntabilitas, Dan Sanksi Perpajakan Terhadap Kepatuhan Wajib Pajak. Jurnal Maksipreneur, 3(1), 1-20.

[14]. Lim, S. A., \& Indrawati, L. (2014). Pengenaan Pajak Penghasilan Untuk Usaha Mikro, Kecil dan Menengah (UMKM) di Indonesia. Jurnal Bisnis Perspektif, 6(1), 1-23.

[15]. Razak, A. A., \& Adafula, C. J. (2013). Evaluating taxpayers attitude and its influence on tax compliance decisions in Tamale, Ghana. Journal of Accounting and Taxation, 5(3), 48-57. https://doi.org/10.5897/jat2013.0120

[16]. Siahaan, S., \& Halimatusyadiah. (2019). Pengaruh Kesadaran Perpajakan, Sosialisasi Perpajakan, Pelayanan Fiskus, Dan Sanksi Perpajakan Terhadap Kepatuhan Wajib Pajak Orang Pribadi. Jurnal Akuntansi, 8(1), 1-14. https://doi.org/10.33369/j.akuntansi.8.1.1-14

[17]. Yusril, M., Handayani, S. R., \& Nuzula, N. F. (2015). Pengaruh Administrasi Perpajakan, Kualitas Layanan Fiskus, Terhadap Perilaku Wajib Pajak Dan Kepatuhan Wajib Pajak (Studi Pada Wajib Pajak Badan Di Kantor Pelayanan Pajak Malang Selatan). Profit (Jurnal Administrasi Bisnis), 9(1), 35-50. https://doi.org/10.21776/ub.profit.2015.009.02.4

\section{SEMINAR PROCEEDING/CONFERENCE}

[18]. Hutasoit, G. (2017). Pengaruh Tax Amnesty Terhadap Kepatuhan Wajib Pajak Di Kota Palembang. In Prosiding Ekonomi \& Bisnis. Developing Social Society for Better Future (pp. 38-43). Palembang: STMIK PalCom Tech.

\section{SKRIPSI, THESIS, DISERTASI}

[19]. Khasanah, L. N. (2016). Kepatuban Wajib Pajak: Faktor-Faktor yang Mempengarubinya (Studi Pada Wajib Pajak PP 46 Tabun 2013 yang Terdaftar di KPP Pratama Surakarta dan Boyolali). Skripsi. Universitas Muhammadiyah Surakarta.

[20]. Mutia, S. P. T. (2014). Pengaruh sanksi perpajakan, kesadaran perpajakan, pelayanan fiskus, dan tingkat pemahaman terhadap kepatuban wajib pajak orang pribadi (Studi Empiris pada Wajib Pajak Orang Pribadi yang terdaftar di KPP Pratama Padang). Skripsi. Universitas Negeri Padang.

[21]. Saputra, R. (2015). Pengaruh Sanksi, Kesadaran Perpajakan, Dan Kualitas Pelayanan Wajib Pajak Terbadap Kepatuban Wajib Pajak Bumi Dan Bangunan (Studi Empiris Pada Wajib Pajak Kabupaten Pasaman). Universitas Negeri Padang. 


\section{E. WEBSITE}

[22]. https://www.liputan6.com/bisnis/read/3581018/ini-alasan-pemerintah-turunkan- pajakumkm-jadi-05-persen. ini alasan pemerintah turunkan pajak UMKM jadi 0,5\%. Diakses pada tanggal 24 Februari 2020. $12: 17$.

[23]. http://www.garudadaily.com/choice-news/sampaikan-spt-tahunan-pph-op-melalui-e-filingplt-gubernur-ingatkan-wajib-pajak-untuk-taat/. Sampaikan SPT tahunan PPh OP melalui EFiling, PLT Gubernur ingatkan Wajib Pajak Untuk Taat. Diakses pada tanggal 24 Februari 2020. $14: 46$.

[24]. https://www.online-pajak.com/ptkp-terbaru-pph-2. PPH pasal 21 : PTKP terbaru (PTKP 20160/PTKP 2018). Diakses pada tanggal 24 Februari 2020, 13.05.

[25]. Peraturan Pemerintah Republik Indonesia Nomor 46 tahun 2013 tentang Pajak Penghasilan atas Penghasilan dari Usaha yang Diterima atau diperoleh Wajib Pajak yang memiliki Peredaran Bruto Tertentu. 2018. Jakarta: Presiden Republik Indonesia.

[26]. Peraturan Pemerintah Republik Indonesia Nomor 23 tahun 2018 tentang Pajak Penghasilan atas Penghasilan dari Usaha yang Diterima atau diperoleh Wajib Pajak yang memiliki Peredaran Bruto Tertentu. 2018. Jakarta: Presiden Republik Indonesia.

[27]. Pratama, M. R. (2012). Analisis Faktor-faktor yang Mempengarubi Kesadaran Wajib Pajak Orang Pribadi Terbadap Kepatuban Kewajiban Perpajakan di Kota Tangerang Selatan. Universitas Bina Nusantara. Jakarta. 